\section{Estudo \\ Ecidebate}

em CAStão

Planejamento
Revista Estudo \& Debate, Lajeado, v. 26, n. 3, 2019. ISSN 1983-036X

DOI: http://dx.doi.org/10.22410/issn.1983-036X.v26i3a2019.2117

\title{
A (I)LEGALIDADE DAS LIMITAÇÓES CONTRATUAIS SOCIETÁRIAS SOBRE A LIBERDADE DE TESTAR E ELEGER REGIME DE BENS NO CASAMENTO
}

\author{
Gastão Marques Francoํㄹ Allan Álvares Contagem de Medeiros ${ }^{2}$
}

\begin{abstract}
Resumo: A realização de um testamento e a escolha do regime de bens no casamento ou uniáo estável são atos que representam a autonomia da pessoa humana para decidir sobre seu próprio patrimônio durante e após a vida, que já é limitada por alguns requisitos legais previstos no ordenamento jurídico. No entanto, uma prática que se torna cada vez mais usual, notadamente nas denominadas empresas familiares, é a imposiçáo de cláusulas que restringem essa liberdade individual, visando a continuidade dos negócios por membros do núcleo familiar gestor da atividade. O presente estudo irá analisar se essas limitaçôes oriundas de uma relação particular entre indivíduo e empresa podem ser consideradas legais, principalmente sob a égide de princípios constitucionais e de direito privado que asseguram a autonomia da pessoa humana no ato de testar e eleger o regime de bens com outro indivíduo.
\end{abstract}

Palavras-chave: autonomia; testamento; regime de bens; cláusulas societárias.

\section{THE (IL)LEGALITY OF CORPORATE CONTRACTUAL LIMITATIONS TO TEST AND ELECT PROPERTY REGIME IN MARRIAGE}

\begin{abstract}
The making of a will and the choice of the property regime in marriage or stable union are acts that represent the autonomy of the human person to decide on their own assets during and after life, which is already limited by some legal requirements in the legal order. However, a practice that is becoming more and more usual, especially in so-called family businesses is the imposition of clauses restricting this individual freedom, aiming at the continuity of business by members of the family unit manager of the activity. The present study will analyze if these limitations arising from a particular relationship between individual and company can be considered legal, mainly under the aegis of constitutional and private law principles that assure the autonomy of the human person in the act of testing and electing the property regime with another individual.
\end{abstract}

Keywords: autonomy; testament; property regime; corporate clauses.

1 Mestrando em Direito nas Relações Econômicas e Sociais pela faculdade Milton Campos. Pós-graduado em Direito Civil Aplicado pela PUC Minas. Bacharel em Direito pela Faculdade Milton Campos. Advogado, Sócio Proprietário em Ferreira Franco Advogados. E-mail: gastaofranco@ferreirafrancoadvogados.com

2 Bacharelando em Direito pela Faculdade Milton Campos. Trainee em Direito Societário em Guimarães e Vieira de Mello. E-mail: allan.acm95@gmail.com 


\section{Introdução}

A modernidade trouxe várias inovações e modificações na dinâmica empresarial, principalmente em decorrência da tecnologia, que passa cada vez mais a permitir a realização de negócios comerciais de maneira célere e simplificada.

Diante dessa nova realidade, passaram a surgir, também cada vez mais, novos arranjos contratuais e empresariais, com o intuito de melhor organizar e trazer segurança para os indivíduos que ingressam na ordem econômica.

No entanto, essa mesma fluidez que facilita a realização de certos negócios pode também prejudicar a perpetuidade de outros já consolidados, como as denominadas empresas familiares, que são aquelas constituídas por membros de um mesmo núcleo familiar (ou entre poucos núcleos familiares, tendo em vista ser este conceito nada pacífico dentre os pesquisadores do tema), podendo exercer diversos tipos de negócios no mercado, unidos por um vínculo intuito personae, nas quais as figuras pessoais dos sócios são o fator preponderante de uniáo entre eles.

Não bastasse a dificuldade de perpetuação dos negócios decorrente das altas, complexas e confusas cargas tributárias, além da onerosa e controversa legislação trabalhista, a interferência estatal nas relaçóes familiares feita no Brasil, com previsões legais e construçôes jurisprudenciais, acabam impactando de forma direta na criação, atuação e sucessão dessas empresas compostas por membros de um mesmo núcleo familiar.

Um exemplo clássico que é considerado como prejudicial na continuidade dessas empresas, cujo conceito será pormenorizado nesse artigo, é a concorrência do cônjuge do autor da herança com os descendentes, que, segundo a legislação e jurisprudência atual, irá ocorrer inclusive nos casos em que estes indivíduos são casados pelo regime da separação convencional de bens.

Ora, sabe-se que muitos empresários, ao constituírem e exercerem uma atividade comercial com seus familiares, não possuem interesse em aceitar um terceiro não pertencente ao núcleo original nessa relação, como o cônjuge ou o companheiro de um familiar que venha a falecer.

Diante desse quadro fático, o denominado planejamento societário, patrimonial e sucessório ganha cada vez mais adeptos entre os empresários, principalmente entre aqueles que buscam a perpetuidade de uma atividade econômica praticada e usufruída exclusivamente por membros de uma mesma entidade familiar.

E é justamente por meio desses planejamentos que os sócios de empresas familiares buscam evitar, a qualquer custo, o ingresso de terceiros no quadro societário, sendo que uma das formas utilizadas é justamente o ponto a ser aprofundado nesse artigo: a vedação expressa no acordo de acionistas ou quotistas quanto à (i) eleição de certos regimes de bens no casamento ou união estável, bem como à (ii) cessão das participaçóes societárias, via testamento ou contratos, a terceiros.

Por meio dessas vedaçóes os sócios buscam, como no primeiro exemplo, evitar que, no caso de divórcio vivenciado por um integrante do grupo familiar, o ex-cônjuge, meeiro, consiga ingressar no quadro societário, ou, como no segundo exemplo acima citado, que 
algum sócio possa realizar um testamento deixando suas participaçóes societárias de emissão da sociedade a terceiro que não familiar.

É certo que existem outras formas para evitar esse ingresso de estranhos na empresa familiar, mas isso não impede que muitos ainda se utilizem desse instrumento no acordo de quotistas ou acionistas.

A pergunta que se pretende responder nesse artigo é: seriam consideradas legais e produziriam efeitos essas restriçóes feitas entre sócios, por um instrumento particular, aos direitos garantidos por lei de testar e eleger o regime de bens de um indivíduo?

Para chegar a uma conclusão favorável, primeiramente serão demonstrados, de forma sucinta, o que seriam o direito de testar e de eleger o regime de bem em um casamento ou união estável, além da importância desses direitos e as limitaçóes legais que já existem sobre eles.

Após essa introdução conceitual, será aprofundado o tema principal desse estudo: a legalidade ou ilegalidade das restriçóes aos direitos destacados, feitas em acordos de quotistas ou acionistas.

A importância dessas restriçóes na prática, o conflito legal e principiológico existente e até o estudo específico dessas cláusulas nas sociedades por ações - haja vista seu caráter, a princípio, de sociedade de capital - são temas que serão abordados para a obtenção de uma resposta satisfatória ao problema.

Pretende-se concluir, por meio do método dialético e da vertente metodológica jurídico dogmática, que a restrição ao direito de testar e eleger regime de bens dos sócios pelo acordo feito entre eles podem limitar a circulação das quotas e açóes da empresa, assim como vedar o ingresso de terceiros no quadro societário, que teriam direito a receber apenas o valor das quotas ou açóes recebidas, sem interferir, diretamente, nos direitos dos sócios.

\section{Os direitos de testar e de eleger o regime de bens no casamento e na uniáo estável}

Antes de iniciar o estudo aprofundado sobre a legalidade das restrições impostas nos acordos entre sócios sobre o direito de testar e eleger o regime de bens, torna-se necessário, antes de mais nada, compreender a importância e a natureza desses direitos previstos no Código Civil de 2002.

O primeiro diz respeito ao direito de dispor em vida sobre a continuação do patrimônio após a morte, enquanto o segundo permite a eleição de uma forma de divisão do patrimônio com outro indivíduo, ambos tendo enorme importância prática no contexto de sucessão das empresas familiares, conforme será analisado adiante.

\subsection{O direito de testar e sua importância prática no contexto empresarial familiar}

Com o fortalecimento da noção de propriedade privada nos indivíduos, o desejo de continuação do patrimônio construído durante a vida passou a ser cada vez mais presente nas sociedades civilizadas (RIZZARDO, 2015, p. 11), motivo pelo qual o ramo do direito das sucessóes, responsável justamente por regular essa continuidade, se tornou tão importante na prática. 
No ordenamento jurídico brasileiro, o Código Civil de 2002 prevê uma ordem natural de continuação desse patrimônio após a morte, baseada na relação de parentesco (pais, filhos, etc.) e de conjugalidade (cônjuge e companheiro), denominada ordem de vocação hereditária ${ }^{3}$.

No entanto, por inúmeros motivos que surgem durante a vida de um indivíduo, ele pode desejar que seu patrimônio náo continue conforme a ordem prevista pela lei, motivo pelo qual é concedido a ele o direito de estabelecer como será feita a divisão e a continuidade daquilo que construiu após sua morte, por, dentre outros meios, do testamento (PEREIRA, 2016, p. 168-171).

O momento de criação da figura do testamento ao longo da história é controverso na doutrina, que, por muitas vezes, aponta sua presença antes mesmo da Lei das XII Tábuas, no Direito Babilônio e até mesmo na China (CATEB, 2015, p.187).

Certo é que o ato de testar representa a soberania da vontade do particular de decidir sobre como será distribuído seu patrimônio e realizada outras disposiçóes após sua morte, observadas as limitaçôes e formalidades previstas pela lei (CATEB, 2015, p. 183-184).

O testamento, portanto, é um negócio jurídico com natureza personalíssima, podendo ser feito apenas pelo testador, não se admitindo a presença de procurador para tal ato, além de dispensar, no momento de sua realização, qualquer tipo de aceitação dos beneficiários (FARIAS e ROSENVALD, 2016, p. 370-371).

$\mathrm{O}$ ordenamento jurídico permite que o testamento possa ser feito por formas ordinárias, representadas pelo testamento público, particular e cerrado, e extraordinárias, quais sejam, o testamento marítimo, militar e aeronáutico (FARIAS e ROSENVALD, 2016, p. 396-397), não sendo necessário o estudo discriminado de cada uma delas nessa oportunidade.

A liberdade de testar deve ser considerada plena (FARIAS e ROSENVALD, 2016, p. 368), sofrendo limitaçóes apenas por previsão legal expressa, regra que terá grande efeito quando da análise principal desse artigo.

A principal limitação legal sobre o direito de testar é a necessidade de respeito da legítima, que representa metade da herança pertencente, por disposição legal, aos herdeiros necessários, motivo pelo qual "a legítima dos herdeiros necessários não poderá ser incluída no testamento." (BRASIL, 2002).

Além disso, podem ser apontadas como limitaçóes ao direito de testar a necessidade de observância dos requisitos formais previstos em lei para a elaboraçáo do testamento, que irão variar conforme a espécie escolhida.

3 Segundo o artigo 1.829 do Código Civil, a ordem natural de sucessão do patrimônio do autor da herança será deferida: “(...) I - aos descendentes, em concorrência com o cônjuge sobrevivente, salvo se casado este com o falecido no regime da comunhão universal, ou no da separação obrigatória de bens (art. 1.640, parágrafo único); ou se, no regime da comunhão parcial, o autor da herança não houver deixado bens particulares; II - aos ascendentes, em concorrência com o cônjuge; III - ao cônjuge sobrevivente; IV - aos colaterais" (BRASIL, 2002). 
Por meio do testamento, o testador poderá não apenas dispor sobre a divisão dos seus bens após sua morte, mas também reconhecer um herdeiro necessário, conceder perdão ao filho indigno, nomear um tutor, dentre outras possibilidades.

O testamento pode ser utilizado, por exemplo, por um sócio de uma empresa familiar, que deseja que suas quotas ou açóes sejam transferidas para um terceiro estranho à sociedade após sua morte, motivo pelo qual os sócios tentam limitar esse direito no acordo de quotistas ou acionistas.

Pode, ainda, servir como instrumento para privilegiar um herdeiro em detrimento de outro, como administrador e principal acionista em uma empresa familiar, em virtude de aptidóes pessoais que o credenciam como a melhor opção na sucessão da empresa, desde que respeitada a legítima.

Nesse contexto, portanto, esse instrumento jurídico "é uma solução a ser utilizada quando se deseja dividir o patrimônio da empresa familiar de forma diferente da prevista em lei” (LEONE, 2005, p. 161).

Percebe-se a importância prática do testamento, principalmente no contexto de sucessão empresarial familiar, que pode ser completamente modificada por um sócio ao testar suas quotas ou açóes para indivíduos estranhos a esse núcleo inicial de indivíduos.

E é justamente em razão das inúmeras hipóteses que um testamento pode afetar a continuidade de uma empresa familiar que os sócios, visando a resguardar o ingresso de terceiros na sociedade, instituem cláusulas e vedações sobre esse direito e sobre a livre circulação das quotas da sociedade, tema que será abordado e analisado posteriormente nesse artigo.

\subsection{O regime de bens no casamento e sua importância prática no contexto empresarial familiar}

O segundo instituto aqui abordado, que pode impactar de forma significativa a continuidade de uma empresa familiar, é o regime de bens adotado pelos sócios ao se casarem ou constituírem uma união estável.

O regime de bens se apresenta como uma compilação de regras, escolhidas pelo casal ou, em certas ocasiões, pela lei, que vão disciplinar as relações econômicas entre os cônjuges ou companheiros, bem como a administração e o domínio dos bens adquiridos antes e durante a relação (GONÇALVES, 2015, p. 445).

Essa necessidade pelo regramento conjugal surgiu, assim como os regramentos sucessórios, com a necessidade do indivíduo de limitar e buscar a perpetuação da propriedade privada, quando dividida com outro ser humano ao longo da vida (PARADA, 2008, p. 30).

Atualmente, a escolha do regime de bens nessas relaçóes irá determinar, por exemplo, como será distribuída a propriedade dos bens adquiridos pelo casal antes e durante a relação em caso de divórcio.

Além disso, devido às regras contidas no ordenamento jurídico brasileiro, essa escolha irá impactar também na concorrência do cônjuge com os demais herdeiros necessários em caso de falecimento de uma das partes. 
Percebe-se a importância prática do regime de bens adotado pelos sócios nas empresas familiares, pois esse poderá permitir, ou não, que o ex-companheiro, no caso de divórcio ou até falecimento do sócio, possa adquirir as quotas ou açóes pela meação ou concorrência na herança, conforme bem ressaltado pela doutrina especializada no tema ao discorrer sobre o caso específico das holdings familiares:

No processo de constituição de uma holding familiar, em que os bens da família serão integralizados na sociedade, é necessário haver correta avaliação dos direitos e deveres de cada componente da família, por isso a identificaçáo do regime de casamento e a compreensão dos direitos daí advindos é parte integrante do planejamento sucessório. (SILVA e ROSSI, 2015, p. 86).

O Código Civil de 2002 prevê cinco tipos de regimes de bens: comunhão parcial, comunhão universal, separação obrigatória de bens, separação convencional de bens e participação final nos aquestos (BRASIL, 2002), cada um com peculiaridades e consequências diversas na relação patrimonial do casal.

No regime da separação obrigatória, por exemplo, cada um será titular do seu próprio patrimônio e no momento da separação, em tese, cada um ficará com os bens que forem de sua titularidade (DIAS, 2015, p. 302). No entanto, devido à uma construção jurisprudencial, mesmo nesse regime o cônjuge poderá ter direito à partilha de algum bem no caso de dissolução do vínculo, sob o fundamento de que houve esforço comum nessa aquisição ${ }^{4}$.

Em contrapartida, no regime da comunhão universal:

Todo o acervo patrimonial - tanto o preexistente ao casamento e pertencente a qualquer dos cônjuges, como tudo o que for adquirido durante a sua vigência - compõe uma só universalidade patrimonial, a ser dividida igualmente entre os cônjuges, no fim do casamento, a título de meação. (DIAS, 2015, p. 302).

Se o regime adotado for o da comunhão parcial, onde divide-se o patrimônio particular de cada um e o patrimônio do casal, em caso de falecimento de uma das partes, o cônjuge sobrevivente terá direito à concorrência com os descendentes no patrimônio particular do autor da herança, conforme a jurisprudência atual do Superior Tribunal de Justiça:

4 Nesse sentido decide, com habitualidade, o Superior Tribunal de Justiça: "AGRAVO INTERNO NO AGRAVO EM RECURSO ESPECIAL. DIVÓRCIO. REGIME DE BENS. SEPARAÇÃO OBRIGATÓRIA. PARTILHA. IMÓVEL. ESFORÇO COMUM DEMONSTRADO. SÚMULA N. 377/STF. PROVA. VALORAÇÃO. PRETENSÃO. REEXAME. SÚMULA N. 7/STJ. AGRAVO NÃO PROVIDO. 1. É imune ao crivo do recurso especial a conclusáo de que o imóvel do casal decorreu de esforço comum dos ex-consortes, nos termos do enunciado n. 7 da Súmula desta Casa. Aplica-se, ademais, a presunção nesse sentido, como ensina o verbete n. 377 da Súmula do Supremo Tribunal federal. (...)." (BRASIL. Superior Tribunal de Justiça. AgInt no AREsp 1257738/DF, Rel. Ministra MARIA ISABEL GALLOTTI, QUARTA TURMA, julgado em 09/10/2018, DJe 23/10/2018. Disponível em: https://ww2. stj.jus.br/processo/revista/inteiroteor/?num_registro=201800498922\&dt_publicacao=23/10/2018 Acesso em: 29 de novembro de 2018.) 
RECURSO ESPECIAL. CIVIL. DIREITO DAS SUCESSÓES. CÔNJUGE SOBREVIVENTE. REGIME DE COMUNHÃO PARCIAL DE BENS. HERDEIRO NECESSÁRIO. EXISTÊNCIA DE DESCENDENTES DO CÔNJUGE FALECIDO. CONCORRÊNCIA. ACERVO HEREDITÁRIO. EXISTÊNCIA DE BENS PARTICULARES DO DE CUJUS. INTERPRETAÇÃO DO ART. 1.829, I, DO CÓDIGO CIVIL. VIOLAÇÃO AO ART. 535 DO CPC. INEXISTÊNCIA. (...) 2. Nos termos do art. 1.829, I, do Código Civil de 2002, o cônjuge sobrevivente, casado no regime de comunhão parcial de bens, concorrerá com os descendentes do cônjuge falecido somente quando este tiver deixado bens particulares. 3. A referida concorrência dar-se-á exclusivamente quanto aos bens particulares constantes do acervo hereditário do de cujus. (...).” (BRASIL. Superior Tribunal de Justiça. REsp 1368123/SP, Rel. Ministro SIDNEI BENETI, Rel. p/ Acórdão Ministro RAUL ARAÚJO, SEGUNDA SEÇÃO, julgado em 22/04/2015, DJe 08/06/2015. Disponível em: https://ww2.stj.jus.br/processo/revista/ inteiroteor/?num_registro=201201031033\&dt_publicacao=08/06/2015 Acesso em: 2 de dezembro de 2018.)

Esses exemplos citados demonstram o impacto da escolha do regime de bens dos sócios no contexto de uma empresa familiar, pois em caso de divórcio ou falecimento desses, o cônjuge ou companheiro poderá adquirir as quotas ou açôes que pertenciam apenas aos integrantes do núcleo familiar.

Em decorrência justamente desses efeitos, os sócios buscam, por exemplo, por um acordo de quotistas ou acionistas, estabelecer como regra que o regime de bens adotado por eles em caso de eventual casamento ou constituição de união estável seja o da separação de bens, ou ainda que, mesmo ao adquirir por meação ou herança as quotas de uma sociedade, esse terceiro não possa ingressar no quadro societário.

Ora, esse tipo de acordo particular pode ser considerado legal e produzir efeitos na prática, contrariando a plena liberdade de escolha do indivíduo sobre o regime de bens adotado no seu casamento?

A resposta para essa indagação, que se estende também para a liberdade de realizar o testamento, será trabalhada no próximo capítulo, que irá analisar todos os fundamentos capazes de fornecer uma conclusão satisfatória.

\section{A (i) legalidade das cláusulas societárias restritivas}

\subsection{A utilizaçáo prática nas empresas familiares por meio de acordos entre sócios}

A importância do problema aqui levantado se justifica pela enorme utilização prática dessas cláusulas que visam a restringir a entrada de terceiros nos quadros das empresas familiares.

Essas empresas, no âmbito do que se deseja analisar no presente artigo, podem ser definidas como aquelas nas quais a operação perpassa pelas diversas geraçóes de um mesmo núcleo familiar (ou poucos núcleos familiares) e que, por este motivo, têm como pano de fundo, seja no âmbito das deliberaçóes entre sócios, seja também no âmbito do próprio exercício da administração, a influência das relaçóes familiares visando a perpetuidade tanto do negócio quanto do controle familiar sobre o negócio. 
Dentro deste panorama, pode-se vislumbrar o vínculo estritamente personalíssimo que liga os sócios de uma empresa familiar, também denominado vínculo "intuitu personae". Nas palavras de Corrêa-Lima (2006, p. 29), "diz-se que uma sociedade é de "pessoas" quando nela predomina o elemento "affectio societatis", quando os sócios nela permanecem, se e enquanto, ligados por vínculos pessoais".

Nítida é a relação estritamente pessoal que liga os sócios de uma empresa familiar, qual seja, mais precisamente, os vínculos de parentesco aos quais são conectados, sendo, desta forma, a empresa familiar um instrumento utilizado não somente para a conquista paulatina do patrimônio, como é o caso das sociedades operacionais, mas também para a blindagem e perpetuação deste patrimônio, como é o caso das holdings familiares 5 .

Neste sentido, tal tipo empresarial inevitavelmente se deparará com um problema delicado: a sucessáo do negócio, ou seja, após a morte de algum sócio, dentro um universo de herdeiros desse sócio falecido, quais são os aptos ao ingresso na empresa familiar, de modo a efetivamente contribuírem com a consecuçáo de seu objeto social e, assim, garantir a perenidade da empresa?

Além disso, tendo em vista a relaçâo estritamente pessoal entre os sócios, o desejo pelo não ingresso de terceiros, como cônjuges e eventuais herdeiros, no quadro societário, é quase que unânime nesses casos.

O problema da sucessão dos negócios familiares é real e assola os patriarcas que, de forma acertada, já pensam no momento de sucessão dentro de sua empresa. Isto porque, apenas a título de curiosidade, de acordo com estudo realizado pela $\mathrm{PwC}$, em 2016, sabe-se que $43 \%$ das empresas familiares no mundo não têm plano de sucessão e, desta forma, $12 \%$ não chegam à terceira geraçăo ${ }^{6}$.

Este dado de pesquisa colhida recentemente, demonstra a consequência da resistência (ou da dificuldade) de se profissionalizar a sucessão e gestão das empresas familiares, tendose como falsa impressão a ideia de que os herdeiros, entendendo-se pelos descendentes dos sócios, são essencialmente legitimados a ingressarem à operação, pelo simples fato de fazerem parte das novas geraçóes daquela família.

Assim, o ingresso à sociedade de indivíduo que, muitas vezes não possui um perfil empreendedor, ou simplesmente não deseja tal futuro, gera sérios riscos à harmonia e ao alinhamento operacional dentro daquela empresa familiar, vez que estaria concedendo-se, no mínimo, poder de voto em reuniôes de sócios quanto àquelas participaçôes societárias herdadas e, não menos importante, poder de voz, de maneira que, no dia a dia empresarial, as consequências poderiam ser danosas.

5 A holding familiar pode ser conceituada como "a empresa que tenha o objetivo de deter bens e participar de outras sociedades que integram o patrimônio da família, tornando-se possível manter o controle das diversas atividades empresariais de que participam por meio de uma única entidade societária." (SILVA e ROSSI, 2015, p. 20)

6 Pesquisa Global Sobre Empresas Familiares 2016. PWC. Disponível em: https://www.pwc.com.br/pt/ setores-de-atividade/empresas-familiares/2017/tl_pgef_17.pdf. Acesso em: 27 nov. 2018. 
Nas sociedades empresárias limitadas, reguladas pelo Código Civil, a princípio, o problema da sucessão desregulamentada é combatido pelo disposto no artigo 1.028, onde está expressamente determinado que as cotas de sócio falecido serão de pronto liquidadas (BRASIL, 2002).

Nota-se que o legislador conferiu, como regra, o caráter de sociedade de pessoas às sociedades empresárias limitadas, ou seja, tal tipo societário se dá pelo vínculo que liga seus sócios, e não meramente pela reunião de capital, como a princípio ocorre nas sociedades por açóes.

Isto porque, quando da morte de sócio, em regra, a propriedade sobre as cotas por ele detidas não são automaticamente transferidas a seus herdeiros, vez que tais participaçóes societárias são liquidadas, ou seja, serão monetariamente apuradas, sendo apenas o seu valor correspondente repassado aos terceiros, não ingressando estes, portanto, nos quadros societários da sociedade.

Entretanto, da mesma maneira pela qual julga-se prejudicial à saúde da empresa a falta de critérios para o ingresso de herdeiros nos quadros societários, permitindo a ocorrência de sucessão irresponsável e impensada, percebe-se que o método de liquidação automática de cotas prevista no artigo $1.028^{7}$ é demasiadamente engessado, inviabilizando totalmente a sucessão nas empresas familiares, de modo que, com o fim da primeira geração, dissolve-se totalmente a sociedade.

Assim, tendo como pano de fundo o inciso I do artigo 1.028 do Código Civil, que permite a disposição dessa regra geral de forma diversa no contrato, interessantes estratégias vêm sendo construídas no âmbito do direito empresarial, de modo que a sucessão familiar dentro das sociedades empresárias ocorram de forma sinérgica para com os propósitos de uma empresa familiar, qual seja, a devida manutenção dos vínculos pessoais (parentesco) que ali prosperam, de maneira que seu objeto social continue a ser desenvolvido por aqueles familiares que se enquadram em requisitos pré-fixados, de forma que, mesmo com o passar das gerações, a harmonia e o patrimônio familiar estarão protegidos.

Frisa-se, ainda, que o problema não se encontra apenas na transferência de participaçóes societárias a herdeiro incapacitado para a vida empresarial, mas também a herdeiros casados (ou que possam se casar) em regimes que não o da separação convencional de bens, pelos motivos analisados no capítulo anterior, quanto aos efeitos patrimoniais do casamento, principalmente no que diz respeito à comunicação de bens.

A preocupação quanto à escolha do regime de bens nos casamentos dos herdeiros deixa de se tornar mero capricho por parte dos patriarcas a partir do momento em que o

7 Segundo o artigo 1.028: "No caso de morte de sócio, liquidar-se-á sua quota, salvo: I - se o contrato dispuser diferentemente; II - se os sócios remanescentes optarem pela dissolução da sociedade; III - se, por acordo com os herdeiros, regular-se a substituiçáo do sócio falecido." (BRASIL, 2002). 
IBGE (Instituto Brasileiro de Geografia Estatística), em pesquisa realizada em 2016, aponta que, neste ano, para cada três casamento registrados, um divórcio ocorreu ${ }^{8}$.

Neste âmbito, o acordo de acionistas, regulado no artigo 118 da Lei no 6.404 de 1976, ou Lei das Sociedades por Açóes, se apresenta como instrumento para a regulaçáo da sucessão no que diz respeito à transferência de participaçóes societárias, podendo versar, entre outras matérias, a respeito da compra e venda de participaçóes societárias, bem como sobre a preferência para adquiri-las.

Preliminarmente, é de se analisar a legalidade na celebração de acordo de cotistas no âmbito de sociedades limitadas, vez que o Código Civil, lei que regulamente tal tipo societário, nada diz a respeito, mas apenas a Lei das Sociedades Por Açóes.

Segundo o parágrafo único do artigo 1.053 do Código Civil, há a possibilidade de, na lacuna da lei, e mediante permissão expressa no contrato social, as sociedades limitadas serem regidas pelo que dispóe a legislação referente às sociedades por açóes (BRASIL, 2002).

Corrêa-Lima, sobre esse tema, aduz que a aplicação subsidiária das normas que regem as Sociedades por Açôes será completamente válida se, de forma expressa, "existir, no contrato social de determinada sociedade limitada, a opção contratual pela aplicação supletiva das normas da sociedade anônima (...)” (CORREAA-LIMA, 2006, p. 36).

Assim, superada a barreira da aplicabilidade do acordo de cotistas no âmbito das sociedades limitadas, passa-se, agora, à breve conceituação do que vem a ser tal documento, que se torna relevante na medida em que será nele onde os sócios irão prever as cláusulas restritivas objeto do presente estudo.

Pode-se definir acordo de acionistas como contrato, sendo assim submetido às regras de todo e qualquer negócio jurídico, aperfeiçoado entre sócios de uma mesma sociedade, que tem por objeto a regulação do exercício dos direitos referentes às suas participaçóes societárias, sejam estes direitos relativos ao exercício do controle, ao voto dos sócios minoritários, ou mesmo à negociabilidade de tais participaçóes societárias (CARVALHOSA, 2015, p. 23).

No mesmo sentido entende Nelson Eizirik, ao dizer que:

O acordo de acionistas constitui um contrato celebrado entre acionistas de determinada companhia visando à composição de seus interesses individuais e ao estabelecimento de normas de atuaçáo na sociedade, harmonizando seus interesses próprios ao interesse social (EIZIRIK, 2011, p. 702).

O acordo de bloqueio, feito justamente por meio do acordo de acionistas, que visa a harmonização de interesses próprios dos sócios ao interesse social, se apresenta, portanto, como uma importante estratégia que promove a proteção quanto ao patrimônio social e familiar, mediante a restrição quanto ao ingresso à sociedade. Segundo Carvalhosa:

8 Segundo a pesquisa, em 2016 foram registrados 1.095 .535 casamentos, ao mesmo passo em que 344.526 divórcios ocorreram. Disponível em: https://agenciadenoticias.ibge.gov.br/media/com_mediaibge/ arquivos/7008b7eee18577ef910339f1cc678bc2.pdf. Acesso em: 20 de dezembro de 2018. 


\begin{abstract}
Os acordos de bloqueio, de natureza unilateral, têm por função restringir a transmissibilidade das açôes, presentes e futuras, dos acionistas convenentes. (...) As cláusulas mais usuais nos acordos de bloqueio contêm a proibição de transmissão de açôes inter vivos durante o prazo de sua duraçáo e a instituição do direito de preferência recíproca na aquisição de açóes a favor dos contraentes. Neste caso, a preferência segue uma ordem e um critério de proporcionalidade de açóes possuídas (em primeiro lugar, aos convenentes em conjunto, ou a um grupo também em conjunto e depois a qualquer dos contratantes isoladamente ou à propria sociedade (açóes em tesouraria) (CARVALHOSA, 2015, p. 272).
\end{abstract}

Nota-se que as possibilidades de matérias a serem trazidas no âmbito dos acordos de bloqueio não são esgotadas pela lei, de modo que cabe aos sócios, dentro dos requisitos de existência, validade e eficácia, a criação de fatores que limitaráo a circulação das participaçóes societárias por eles detidas.

Dessa forma, os sócios serão livres para dispor sobre esses acordos e seu conteúdo, uma vez que a lei que regula o tema não especifica as matérias que neles poderão constar, sendo limitados apenas pela legalidade de seu objeto conforme o interesse social (EIZIRIK, 2011, p. 703).

Assim, com base na liberdade conferida aos sócios quando da contratação de acordo de cotistas, percebe-se que, com intuito de se resguardar o vínculo personalíssimo o qual rege as empresas familiares, bem como o de se proteger o patrimônio familiar das mãos de terceiros, como não familiares e cônjuges, é que se nota a ampla utilização de acordos de bloqueio no âmbito dessas sociedades, mediante a previsão de cláusulas que expressamente vedam o ingresso de quaisquer indivíduos que não sejam descendentes do sócio morto, cedente ou testador, ou, ainda, vedam até mesmo o ingresso de herdeiros, mas que casados em regimes que náo o da separaçáo convencional de bens, por demonstrarem potencial risco quanto à continuação do patrimônio familiar.

Deste modo, com as limitaçóes acima discriminadas, pautadas na liberdade contratual aos sócios conferida, é possível que se perpetue a propriedade das participaçôes societárias da sociedade única e exclusivamente na mão de familiares, de forma que quaisquer terceiros, até mesmo cônjuges, jamais farão parte dos quadros sociais daquelas sociedades.

\title{
3.2 A aplicaçáo nas sociedades por açóes das cláusulas restritivas ao ingresso de terceiros
}

Essas cláusulas restritivas descritas acima, que vedam o ingresso de terceiros nos quadros societários das empresas familiares, devem ser analisadas de forma pormenorizada no caso das sociedades por açôes, que possuem como traço característico a livre transferências de suas açóes (EIZIRIK, 2011, p. 236).

Como regra, o que impera nessas sociedades é o trabalho realizado em cima do capital ali aportado, sendo que, ao contrário do que ocorre na figura das sociedades empresárias limitadas, fica em segundo plano a figura do acionista, não havendo, a priori, quaisquer vínculos pessoais entre os acionistas para que a sociedade desempenhe de forma competente o seu objeto social. Nesse sentido: 
Na sociedade anônima, o que ganha relevância é a aglutinação de capitais, não importando a pessoa dos sócios. A cada sócio é indiferente a pessoa dos demais sócios, náo havendo entre estes o chamado intuitu personae.

A associação é, na verdade, de capitais, pois estes é que são fundamentais para a existência e continuidade da sociedade. Esses capitais têm, evidentemente, titulares, mas estes titulares podem variar constantemente, até diariamente, sem que a sociedade seja formalmente afetada. (BORBA, 2018, p. 169).

Entretanto, a relação "intuitu pecuniae" que prospera no âmbito das sociedade por açóes pode ser relativizada, tendo em vista permissivo legal, localizado no artigo 36 da Lei das S.A., que permite a confecção de regras, no âmbito do Estatuto Social da companhia, que limitam a circulação das açóes por ela emitidas, desde que quatro requisitos sejam atendidos, quais sejam: (i) a companhia deve ser obrigatoriamente fechada; (ii) o estatuto social regule detalhadamente as regras quanto à limitação da circulação de açóes; (iii) tais regras não impeçam totalmente a circulação das açóes; e (iv) as regras tecidas no âmbito do estatuto social não submetam o acionista ao livre arbítrio dos órgãos de administração nem à maioria dos acionistas da companhia.

Deste modo, consegue-se vislumbrar a possibilidade de se constituir empresas familiares por meio de companhias fechadas, desde que, no estatuto social, sejam explicitadas de forma taxativa e em conformidade com os demais requisitos do artigo 36 da Lei das S.A., as restriçốes que limitam a circulação das açóes daquela sociedade.

Ainda mais a fundo, percebe-se que a lei também náo cria empecilhos para que a companhia, por meio de previsão expressa no estatuto social, impeça que a propriedade sobre as açóes apenas seja transferida a descendentes de acionistas que casados no regime da separação convencional de bens. Isto porque, tais restriçôes, se devidamente explicitadas, não impedem totalmente a circulação das açóes, bem como náo sujeitam o acionista ao livre arbítrio da administração e nem da maioria dos acionistas da companhia. Além disso:

\footnotetext{
Outras restriçôes também são admitidas, como, por exemplo, as que exigem certa qualidade para ser sócio, determinada profissão, nacionalidade, as cláusulas de opção de compra de açôes, etc; o importante é que as limitaçôes à circulação das açôes não impeçam a sua transferência e sejam rigorosamente especificadas e reguladas no estatuto social. (EIZIRIK, 2011, p. 239).
}

Portanto, entende-se que as companhias fechadas, constituídas mediante as previsóes que limitam a circulaçáo de suas açóes em sede de seu respectivo estatuto social, podem adquirir caráter de sociedade de pessoas, tendo em vista que, a partir da criação de tal regramento, é demonstrado que a pessoa de cada um dos acionistas que compóem o capital social daquela companhia é essencial para a consecução do objeto social e, ainda, que o vínculo familiar que os une é o motivo maior para a própria constituiçâo daquela companhia, sendo que, assim, náo é do interesse da companhia e nem dos acionistas a presença de sócios que não contemplem tais características.

Ou seja, a aplicabilidade das cláusulas restritivas que atingem os beneficiados por testamento ou pelo regime de bens, estranhas ao núcleo familiar que compóe a sociedade, também possuem importante aplicabilidade nas sociedades por ações. 


\subsection{A (i) legalidade das cláusulas restritivas sobre os direitos de testar e eleger regime de bens}

Percebeu-se por todo o demonstrado, que o vínculo pessoal característico das empresas familiares pode ser mantido por meio de cláusulas que restringem o ingresso de terceiros estranhos a esse núcleo na sociedade.

No entanto, a indagação que se pretende responder nesse estudo é se essas cláusulas ferem, de alguma maneira, o direito de testar e eleger regime de bens dos indivíduos, já que podem, por exemplo, impedir que um beneficiário de testamento ou ex-cônjuge ingressem nos quadros societários em virtude da morte do sócio e/ou divórcio.

Conforme exposto no capítulo anterior, o direito de testar é decorrente da própria autonomia privada dos indivíduos, que são livres para decidir sobre a disposição de seu patrimônio após a morte, tendo inclusive fundamento constitucional, conforme brilhantemente ensinam Cristiano Chaves e Nelson Rosenvald:

\footnotetext{
É certo e incontroverso que o fundamento essencial da sucessão testamentária é a autonomia privada, marca registrada dos negócios jurídicos como um todo, como decorrência inexorável da liberdade - que é núcleo duro da dignidade humana. (...)

Para além disso, relembrando que o direito sucessório é corolário do exercício do direito constitucional da propriedade privada ( $\mathrm{CF}$, art. $5^{\circ}$, XXII e XXX), observamos que a regra geral há de ser a plena liberdade de testamento, reconhecendo ao titular a livre disposição de seus bens. (FARIAS e ROSENVALD, 2016, p. 368).
}

Em relação à escolha do regime de bens, esse também se apresenta como uma manifestação da autonomia privada do casal, ao decidir sobre a forma que será dividido o patrimônio entre eles (DIAS, 2015, p. 300).

Para responder ao problema aqui proposto, deve-se avaliar se as cláusulas restritivas ao ingresso de terceiros nas empresas familiares afetam, de fato, o direito de testar e eleger regime de bens dos sócios.

A primeira conclusão que se propõe é que nenhum tipo de cláusula poderá impedir qualquer indivíduo, mesmo sendo sócio de uma empresa, de exercer seu direito de realizar testamento e escolher regime de bens, pois esses são garantidos de forma expressa na lei, que também é responsável por delinear seus limites.

Mas, em relação às cláusulas expostas nesse capítulo, notadamente aquelas incluídas nos chamados acordos de bloqueio, que impedem o ingresso de terceiros nas sociedades e que, porventura, tenham recebido as cotas, somente terão direito ao recebimento de seu valor, monetariamente apurado, estariam de fato restringindo os direitos de testar e eleger regime de bens?

A resposta que se apresenta mais plausível para essa pergunta, diante de todo o exposto, é que não estariam sendo infringidos tais direitos, pois esses integrantes das empresas familiares continuarão livres para testar e eleger regime de bens, entretanto, não farâo parte dos quadros societários da empresa familiar os terceiros beneficiados por uma eventual herança ou meação, tendo em vista o disposto no estatuto social ou acordo de acionistas/cotistas. 
Desta feita, o que acontecerá é: a apuração dos haveres quanto às participações às quais têm direito e a respectiva indenização, pelo método de apuração de haveres fixado, ou a (re) compra de tais participaçóes pelos sócios da sociedade ou até mesmo pela sociedade, mediante exercício de direito de compra (call option), caso previsto nos documentos societários da sociedade.

Além disso, um sócio de determinada empresa familiar, que opte por eleger um regime de bens, por exemplo, vedado pelo contrato social, poderá se retirar da sociedade, nos mesmos termos do exposto acima, não tendo nenhum direito restringido na prática.

Portanto, desde que essas vedações impostas pelos integrantes de uma empresa familiar não afetem o direito propriamente dito de realizar o testamento o eleger regime de bens, serão completamente legais e produzirão seus efeitos.

\section{Conclusóes finais}

Pretendeu-se nesse artigo analisar se as cláusulas presentes, muitas vezes, nas empresas familiares, que restringem de alguma forma o direito de realizar testamento e eleger regime de bens dos sócios se apresentarão como legais e válidas perante nosso ordenamento jurídico.

Para isso, foi realizado um breve estudo sobre a importância do testamento e do regime de bens, ressaltando suas grandes implicaçóes práticas no contexto de planejamento sucessório dessas empresas compostas por membros de um mesmo núcleo familiar.

Após esse estudo introdutório, procurou-se demonstrar a aplicabilidade prática dessas cláusulas restritivas e suas implicaçóes, além das diversas formas que elas podem se apresentar para atingir o mesmo objetivo: a continuidade dos negócios pelos membros da mesma família.

Foi obtida a seguinte conclusão: a devida e correta pormenorização de cláusulas que apenas proíbem o ingresso de terceiros, ou até mesmo de herdeiros que não casados pelo regime da separação convencional de bens na sociedade, não se apresentam como afronta a quaisquer direitos inerentes às pessoas acima citadas.

Isto porque, foi analisada a questáo sob dois contextos: quanto aos direitos e obrigaçóes das pessoas naturais relativas aos sócios, herdeiros e terceiros não familiares; mas, de outro lado, quanto aos direitos e obrigaçóes das pessoas jurídicas objeto do regramento analisado nesse estudo.

Ora, deve-se entender que as empresas familiares, dotadas de personalidade jurídica, são, por consequência, sujeitos que devem ter sua vontade observada e respeitada pela coletividade, sendo que não apenas os sócios são a elas vinculados, mas também terceiros leia-se os cônjuges e herdeiros de sócios.

Assim, quanto às pessoas naturais acima citadas, nota-se que o direito de elegerem regime de bens ou de testarem permanece intacto, não sendo, de forma alguma limitados. Entretanto, efeitos reflexos a esta liberalidade ocorrerão no âmbito interno da sociedade: no caso dos herdeiros que casados pelo regime que não o da separação convencional de bens, seu casamento é notoriamente válido, entretanto, por desrespeitar regramento objetivo 
referente a requisito de ser aceito como sócio, apenas não ingressará no quadro societário daquela pessoa jurídica.

O mesmo ocorrerá com terceiro não familiar contemplado com participaçóes societárias em testamento: o testador verá sua vontade de transmitir a propriedade sobre aquelas participaçóes societárias respeitada, entretanto, o terceiro, por não cumprir requisito objetivo quanto ao ingresso à sociedade, não será sócio, mas será ressarcido mediante a apuração dos haveres aos quais tem direito.

\section{Referências}

BORBA, José Edwaldo Tavares. Direito Societário. 16 ed. São Paulo: Atlas, 2018.

BRASIL. Código Civil: Lei no 10.406, de 10 de janeiro de 2002. Brasília: Presidência da República, 2002. Disponível em: < http://www.planalto.gov.br/ccivIl_03/Leis/2002/ L10406.htm\#art997> Acesso em: 30 nov. 2018.

BRASIL. Sociedades Por Açóes: Lei no 6.404, de 15 de dezembro de 1976. Brasília: Presidência da República, 1976. Disponível em : < http://www.planalto.gov.br/ccivil_03/ LEIS/L6404consol.htm> Acesso em: 28 nov. 2018.

BRASIL. Superior Tribunal de Justiça. AgInt no AREsp 1257738/DF, Rel. Ministra MARIA ISABEL GALLOTTI, QUARTA TURMA, julgado em 09/10/2018, DJe 23/10/2018. Disponível em: https://ww2.stj.jus.br/processo/revista/inteiroteor/?num_ registro=201800498922\&dt_publicacao=23/10/2018. Acesso em: 29 de novembro de 2018

BRASIL. Superior Tribunal de Justiça. REsp 1368123/SP, Rel. Ministro SIDNEI BENETI, Rel. p/ Acórdão Ministro RAUL ARAÚJO, SEGUNDA SEÇÃO, julgado em 22/04/2015, DJe 08/06/2015. Disponível em: https:/ww2.stj.jus.br/processo/revista/ inteiroteor/?num_registro=201201031033\&dt_publicacao=08/06/2015. Acesso em: 2 de dezembro de 2018.

CARVALHOSA, Modesto. Acordo de Acionistas: Homenagem a Celso Barbi Filho. 2 ed. São Paulo: Saraiva, 2015.

CORRÊA-LIMA, Oscar Brina. Sociedade Limitada. 1 ed. Rio de Janeiro: Forense, 2006.

DIAS, Maria Berenice. Manual de direito das famílias. 10a ed. São Paulo: Editora Revista dos Tribunais, 2015.

EIZIRIK, Nelson. A Lei das S/A Comentada. Volume I - Arts. $1^{\circ}$ a 120. São Paulo: Quarter Latin, 2011. 
ESTATÍSTICAS do Registro Civil - 2016. IBGE. Disponível em:

$<$ https://agenciadenoticias.ibge.gov.br/media/com_mediaibge/

arquivos/7008b7eee18577ef910339f1cc678bc2.pdf> Acesso em: 26 nov. 2018.

FARIAS, Cristiano Chaves de; ROSENVALD, Nelson. Curso de Direito Civil:

Sucessóes. 2a ed. Salvador: Ed. JusPodivm, 2016.

GONÇALVES, Carlos Roberto. Direito civil brasileiro: Direito de Família. 12a ed. São Paulo: Saraiva, 2015.

LEONE, Nilda Maria de Clodoaldo Pinto Guerra. Sucessáo na empresa familiar: preparando as mudanças para garantir sobrevivência no mercado globalizado. São Paulo: Atlas, 2005.

PARADA, Deise Maria Galvão. Regime de bens entre cônjuges. São Paulo: Quartier Latin, 2008.

PEREIRA, Caio Mário da Silva. Instituiçóes de Direito Civil: V. 6 Direito das Sucessóes. 23a ed. Rio de Janeiro: Forense, 2016.

PESQUISA Global Sobre Empresas Familiares 2016. PWC. Disponível em: <https:// www.pwc.com.br/pt/setores-de-atividade/empresas-familiares/2017/tl_pgef_17.pdf> Acesso em: 27 nov. 2018.

RIZZARDO, Arnaldo. Direito das sucessóes. 9a ed. Rio de Janeiro: Forense, 2015.

SILVA, Fábio Pereira da; ROSSI, Alexandre Alves. Holding familiar: visão jurídica do planejamento societário, sucessório e tributário. São Paulo: Trevisan Editora, 2015. 